\title{
Growth of soil algae and cyanobacteria on gold mine tailings material
}

\section{AUTHORS: \\ Tanya Seiderer $^{1}$ \\ Arthurita Venter $^{1}$ \\ Fanus van Wyk ${ }^{1}$ \\ Anatoliy Levanets ${ }^{1}$ \\ Anine Jordaan ${ }^{1}$ \\ AFFILIATION: \\ ${ }^{1}$ Unit for Environmental Sciences and Management, North-West University, Potchefstroom, South Africa}

\section{CORRESPONDENCE TO: Anatoliy Levanets}

EMAIL:

20868421@nwu.ac.za

\section{DATES:}

Received: 09 Dec. 2016

Revised: 02 May 2017

Accepted: 20 June 2017

\section{KEYWORDS:}

revegetation; biological soil crusts; cyanobacteria; tailings storage facilities; scanning electron microscopy

\section{HOW TO CITE:}

Seiderer T, Venter A, Van Wyk F, Levanets A, Jordaan A. Growth of soil algae and cyanobacteria on gold mine tailings material. S Afr J Sci. 2017;113(11/12), Art. \#2016-0384, 6 pages. http://dx.doi.org/10.17159/ sajs.2017/20160384

\section{ARTICLE INCLUDES: \\ $\times$ Supplementary material \\ $\times$ Data set}

FUNDING:

None

(C) 2017. The Author(s). Published under a Creative Commons Attribution Licence.
The goal of revegetation of gold mine tailings storage facilities is to reduce aeolian pollution, nutrient leaching and erosion caused by exposure to wind and water. The establishment of biological soil crusts may prove to be a more cost-effective way to reach the same goal and the aim of this study was therefore to determine if it is possible to establish algae and cyanobacteria on gold mine tailings. Different treatments of Chlamydomonas, Microcoleus and Nostoc were inoculated on gold mine tailings in controlled conditions and algal growth was measured on all of the treatments after 6 weeks. Nostoc treatments had the highest chlorophyll-a concentrations and produced a surface crust, while Chlamydomonas treatments penetrated the tailings material and provided the strongest crust. The results were promising but more research is necessary to determine the best organism, or combination of organisms, to colonise mine tailings and to eventually produce biological crusts.

\section{Significance:}

- Determination of the best organisms to colonise mine tailings and to produce biological crusts for the revegetation of gold mine tailings storage facilities.

\section{Introduction}

Tailings storage facilities (TSFs) are hydraulically deposited mine residue storage facilities for potential harmful waste products such as waste rock, cyanided sand, slimes, surplus mine water and discarded solutions ${ }^{1}$, also known as tailings material or mill tailings'2. Uncovered slopes and sparse vegetation is a common sight on tailings material and these surfaces are exposed to the erosive forces of wind and water. Because of the often compacted nature of the material, decreased infiltration of water increases the possibility of run-off, erosion, sedimentation and air pollution through the generation of dust from the tailings material. ${ }^{3}$ Dust emissions from the tailings may have health effects on communities in the vicinity of TSFs ${ }^{1,4}$ and one of the goals of revegetation of these facilities is to reduce or eliminate human and wildlife exposure to contaminants that may be transported by airborne mine tailings ${ }^{5}$. The presence of acids and the high salt content of gold tailings material are likely synergistic in causing biotoxicity as low pH generally increases the bioavailability of metals. ${ }^{6}$ As a result, most gold mine TSFs are devoid of vegetation and have a stressed heterotrophic microbial community. 5,7

Rehabilitation methods implemented to reduce the environmental impact of erosion on TSFs include gravel mulching, rock cladding and vegetation establishment.,8 The plant canopy reduces aeolian dispersion while the plant roots prevent water erosion and nutrient leaching. ${ }^{5}$ The establishment of vegetation for rehabilitation purposes is a very costly process because of the possible toxicity of heavy metals and immobilisation of some essential nutrients. ${ }^{2}$ Therefore there is a great need for a cost-effective alternative to revegetate tailings material and provide reliable protection against erosion by wind and water.

Biological soil crusts (BSCs) consisting of bryophytes, lichens, algae and associated microorganisms are known to establish in extreme environments $\mathrm{s}^{9-11}$ such as mine tailings ${ }^{12,13}$ and can contribute significantly to the stabilisation of soils through soil aggregate formation ${ }^{14-17}$. BSCs could therefore potentially provide protection against the erosive forces of wind and water on tailings material. Improved stability of soil inoculated with cyanobacteria has been identified ${ }^{18}$ after only 6 weeks as a result of cyanobacteria binding and gluing aggregates and isolated mineral particles.

The aim of our study was to investigate establishment of algae and cyanobacteria on gold mine tailings in controlled conditions and to use scanning electron microscopy (SEM) to determine the success of colonisation. The first step was to establish a protocol for inoculation of algae and cyanobacteria on tailings material that can be used in the controlled study as well as in situ.

\section{Materials and methods}

\section{Characterisation of the tailings material}

Tailings material was collected from a gold mine TSF near Stilfontein $\left(26.48^{\circ} \mathrm{S}, 26.47^{\circ} \mathrm{E}\right)$ in South Africa, and analysed in accordance with the standards set out by the Agricultural Laboratory Association of Southern Africa and the International Soil Analytical Exchange (Wageningen, the Netherlands). ${ }^{19}$ Exchangeable $\mathrm{Ca}, \mathrm{Mg}, \mathrm{K}$ and $\mathrm{Na}$ were estimated by $1 \mathrm{M}$ ammonium acetate $(\mathrm{pH}=7)$, $\mathrm{P}$ was estimated by $\mathrm{P}$-Bray 1 extraction, $\mathrm{pH}$ was estimated via 1:2.5 extraction and conductivity was determined with a saturated extraction as described in NSSSA. ${ }^{19}$

Algal and cyanobacterial species present in the tailings material before inoculation and for all treatments following the 6-week trial period were determined by the methods described by Orlekowsky et al. ${ }^{12}$

\section{Test organisms}

The chlorophycean Chlamydomonas sp. and the cyanobacteria Microcoleus vaginatus and Nostoc sp. were isolated from the collected tailings material. The isolations were made by incubating tailings material on $1.5 \%$ 
agarised Bold's basal growth medium (BBM) $)^{20,21}$ in Petri plates at $20{ }^{\circ} \mathrm{C}$ in continuous light supplied from Philips Lifemax (TLD 58W/840) at $35 \mu \mathrm{mol}$ photons $/ \mathrm{m}^{2} / \mathrm{s}$ (standard conditions). Following 14 days incubation, discrete colonies were transferred to fresh agarised medium in Petri plates in order to obtain unialgal cultures. Each species was then transferred to $100 \mathrm{~mL} \mathrm{BBM}{ }^{21}$ and grown under standard conditions.

Cultures of Chlamydomonas sp., M. vaginatus and Nostoc sp. used for inoculation were grown in $200 \mathrm{~mL} \mathrm{BBM}^{21}$ under standard conditions until they reached the exponential growth phase.

\section{Inoculation of tailings}

The effectiveness of three inoculation methods was compared using Chlamydomonas sp. The three methods were:

1. A volume of $200 \mathrm{~mL}$ of Chlamydomonas sp. suspended in BBM was evenly poured onto the surface of tailings.

2. A volume of $200 \mathrm{~mL}$ Chlamydomonas sp. suspended in $1 \%$ agarised BBM was evenly poured on the surface of tailings.

3. A volume of $200 \mathrm{~mL}$ of Chlamydomonas sp. suspended in BBM was sprayed over the surface of tailings using a 2-L adjustable Thema spray bottle (Thema Home Kitchen Essentials).

\section{Glasshouse trials}

Rectangular seed trays ( $300 \times 275 \times 100 \mathrm{~mm}$ ) were filled to a depth of $80 \mathrm{~mm}$ with gold mine tailings material and placed in a glasshouse in which the air temperature varied between $26^{\circ} \mathrm{C}$ during the day and $20^{\circ} \mathrm{C}$ at night. The light intensity ranged from 50 to $300 \mu \mathrm{mol}$ photons $/ \mathrm{m}^{2} / \mathrm{s}$ depending on the time of day. Unsterilised tailings material was used because sterilisation by autoclaving resulted in excessive growth of fungi during the experiments.

Cultures grown in $200 \mathrm{~mL}$ BBM-agar suspension ${ }^{21}$ were carefully poured over the tailings material. Considering high cost as a factor in tailings revegetation projects, cultures of algae and cyanobacteria were grown in both full strength and half strength BBM. The different treatments are shown in Table 1. There were three replicates of each.

Table 1: Treatments tested in the glasshouse

\begin{tabular}{|c|c|c|c|c|c|}
\hline \multirow[b]{2}{*}{ Treatment $^{\dagger}$} & \multirow[b]{2}{*}{ Inoculum } & \multirow[b]{2}{*}{ Water } & \multicolumn{3}{|c|}{ Agarised Bold's basal medium } \\
\hline & & & $\begin{array}{c}\text { Full } \\
\text { strength }\end{array}$ & $\begin{array}{c}\text { Half } \\
\text { strength } \\
\mathrm{PO}_{4}^{3-}\end{array}$ & $\begin{array}{c}\text { Half } \\
\text { strength } \\
\mathrm{NO}_{3}^{-}\end{array}$ \\
\hline 1 & - & + & & & \\
\hline 2 & - & & + & & \\
\hline 3 & - & & & + & \\
\hline 4 & - & & & & + \\
\hline 5 & Chlamydomonas & & + & & \\
\hline 6 & Microcoleus & & + & & \\
\hline 7 & Nostoc & & + & & \\
\hline 6 & Chlamydomonas & & & + & \\
\hline 9 & Microcoleus & & & + & \\
\hline 10 & Nostoc & & & + & \\
\hline 11 & Chlamydomonas & & & & + \\
\hline 12 & Microcoleus & & & & + \\
\hline 13 & Nostoc & & & & + \\
\hline
\end{tabular}

${ }^{+}$Soils in all treatments contained the natural soil microflora.
The trays were placed at random positions and watered for short intervals 5 times a day. After 3 weeks, $200 \mathrm{~mL}$ BBM growth medium (without any organism) was added to Treatments $2-13$. Treatments 3 and 4 as well as Treatments 8-13 received $200 \mathrm{~mL}$ BBM with the same phosphate and nitrate concentrations that were initially added (see Table 1).

\section{Chlorophyll-a determination}

After 6 weeks, $10 \mathrm{~g}$ soil was collected to determine the chlorophyll-a concentration using the method described by Castle ${ }^{22}$. The soil sample in $9 \mathrm{~mL}$ methanol solution ( $2 \%$ ammonium acetate in $100 \%$ methanol) was placed on a shaker for $4 \mathrm{~h}$, after which the sample was filtered through a Whatman GF/C filter. The absorbance of the supernatant was determined at $652 \mathrm{~nm}, 665 \mathrm{~nm}$ and $750 \mathrm{~nm}$. To calculate the chlorophyll-a concentrations the following equation from Porra et al. ${ }^{23}$ was used:

$\mu \mathrm{g}$ Chla/g soil $\left.=[16.29 *(A 665-\mathrm{A} 750)-8.54 *(\mathrm{~A} 652-\mathrm{A} 750)]^{*} \mathrm{~V}\right) / \mathrm{g}$ soil;

where $\mathrm{V}$ is the volume of solvent used $(\mathrm{mL})$.

\section{Penetration tests}

Before inoculation, penetration tests were done on the dry tailings material with a handheld penetrometer that measures the force (in $\mathrm{kg} / \mathrm{cm}^{2}$ ) needed to break a soil crust. The penetration tests were repeated 3 weeks after the trial on dry soil. Three penetration tests were performed on each replicate of each treatment.

\section{Scanning electron microscopy}

After the 6-week period, three trays of each treatment were left to dry out for SEM analyses. An area of $1 \mathrm{~cm}^{2}$ of the soil surface was sampled using a scalpel blade. Following the method of Tiedt et al. ${ }^{24}$, the samples were put in $4 \%$ osmium vapour; dried and mounted on aluminium stubs using carbon tape and Leit $\mathrm{C}$ plus (Analytical Laboratory Solution). The mounted samples were sputter coated with gold-palladium and observed in a FEI Quanta 250 FEG scanning electron microscope at $8 \mathrm{kV}$.

\section{Data analysis}

The differences between the data sets were determined with Statistica version 13 software. The Kruskal-Wallis ANOVA was used (non-parametric data) for comparing multiple independent samples to determine differences between the different treatments. Standard error bars were also added to graphs (Figures 1 and 2) to indicate the variability of the data.

\section{Results}

\section{The chemistry of the tailings material}

The chemical analysis of the tailings material used is given in Table 2 .

\section{Chlorophyll-a and penetration measurements}

There was a statistically significant difference between the chlorophyll-a of the control treatment that received only water (Treatment 1) and treatments $M$. vaginatus + agar (6), Nostoc sp. + agar (7), M. vaginatus $+\mathrm{PO}_{4}(9)$, Nostoc sp. $+\mathrm{PO}_{4}(10)$, M. vaginatus + $\mathrm{NO}_{3}$ (12) and Nostoc sp. $+\mathrm{NO}_{3}$ (13) (Table 3). The chlorophyll-a of Treatment 2 with BBM and agar and no organism also differed significantly from treatments $M$. vaginatus + agar (6), Nostoc sp. + agar (7), M. vaginatus $+\mathrm{PO}_{4}(9)$, Nostoc sp. $+\mathrm{PO}_{4}(10)$, M. vaginatus $+\mathrm{NO}_{3}$ (12) and Nostoc sp. $+\mathrm{NO}_{3}$ (13). Treatments 3 and 4 (both with no organisms) as well as Treatment 11 (Chlamydomonas sp. $+\mathrm{NO}_{3}$ ) differed significantly from treatments Nostoc sp. + agar (7), $M$. vaginatus $+\mathrm{PO}_{4}(9)$ and $M$. vaginatus $+\mathrm{NO}_{3}(12)$ while Treatment 8 (Chlamydomonas sp. $+\mathrm{PO}_{4}$ ) differed significantly from treatments Nostoc sp. + agar (7) and M. vaginatus $+\mathrm{NO}_{3}(12)$ (Table 3). There was no statistically significant difference between the controls and Chlamydomonas sp. treatments (5, 8 and 11). 
Table 2: $\quad$ Physical and chemical analysis of the gold mine tailings soil

\begin{tabular}{l|c}
\hline \multicolumn{1}{c|}{ Soil analyses } & Gold mine tailings (<5\% pyrite) \\
\hline $\mathrm{pH}\left(\mathrm{H}_{2} \mathrm{O}\right)$ & 5.4 \\
\hline $\mathrm{EC}(\mathrm{mS} / \mathrm{m})$ & 193 \\
\hline $\mathrm{SO}_{4}(\mathrm{mg} / \mathrm{kg})$ & 1674 \\
\hline $\mathrm{P}(\mathrm{mg} / \mathrm{kg})$ & 1 \\
\hline $\mathrm{K}(\mathrm{mg} / \mathrm{kg})$ & 30 \\
\hline $\mathrm{Ca}(\mathrm{mg} / \mathrm{kg})$ & 1793 \\
\hline $\mathrm{Mg}(\mathrm{mg} / \mathrm{kg})$ & 94 \\
\hline $\mathrm{Na}(\mathrm{mg} / \mathrm{kg})$ & 9 \\
\hline $\mathrm{CEC}(\mathrm{cmol} / \mathrm{kg})$ & 1.3 \\
\hline $\mathrm{Al}(\mathrm{cmol} / \mathrm{kg})$ & 0.04 \\
\hline $\mathrm{As}(\mathrm{mg} / \mathrm{kg})$ & 0.05 \\
\hline $\mathrm{Fe}(\mathrm{mg} / \mathrm{kg})$ & 10.53 \\
\hline $\mathrm{Mn}(\mathrm{mg} / \mathrm{kg})$ & 14.90 \\
\hline $\mathrm{Pb}(\mathrm{mg} / \mathrm{kg})$ & Not detected \\
\hline $\mathrm{Zn}(\mathrm{mg} / \mathrm{kg})$ & 1.58 \\
\hline
\end{tabular}

$E C$, electrical conductivity
All the Nostoc treatments grew well. Treatment 7 - the Nostoc-BBMagar suspension $(34.44 \mu \mathrm{g} / \mathrm{g})$ - and Treatment 10 - the Nostoc-BBMagar suspension with $8.1 \mathrm{~g} / \mathrm{L} \mathrm{PO}_{4}(32.52 \mu \mathrm{g} / \mathrm{g})$ - had the highest chlorophyll-a measurements (Figure 1). There was no statistical difference between these treatments and Treatment 13 in which Nostoc was grown in $9.12 \mathrm{~g} / \mathrm{L} \mathrm{NO}_{3}$. Treatments with no test organism as well as treatments with Chlamydomonas sp. as test organism did not grow well.

The chlorophycean Chlorococcum sp. and species of the cyanobacteria Nostoc, Phormidium and Scytonema were present in the tailings material before inoculation. Table 4 shows that some organisms present in the tailings material before inoculation did not survive after the 6-week trial period. On the other hand, opportunistic genera such as Arthrospira, Calothrix, Chlorolobion, Chlorosarcinopsis, Klebsormidium, Lyngbya, Navicula, Stichococcus and Tetracystis were found after the 6-week trial period in different treatments.

Penetration was measured after the treatments were allowed to dry out. Tailings material with Chlamydomonas sp. cultured in BBM-agar suspension (Treatment 5) needed the greatest force to break the soil crust $\left(2.58 \mathrm{~kg} / \mathrm{cm}^{2}\right.$; Figure 2) but the force required did not differ significantly from that of the other treatments. The force required to penetrate the crust of the control differed significantly $(p=0.02)$ from the force required to penetrate the crust of Chlamydomonas cultured in BBM-agar suspension with $8.1 \mathrm{~g} / \mathrm{L}$ (Treatment 8 ).

Spraying delivered a more even coverage of the suspension but this method had a negative effect on the organisms and caused erratic growth. Pouring without agar showed a high initial growth but the chlorophyll-a concentrations (data not shown) declined from Day 6 onwards. The BBM-agar suspension that was poured on the surface proved to be the best method to inoculate algae and cyanobacteria into the soil.

Table 3: The $p$-values of chlorophyll-a measurements in comparisons of treatments showing a significant difference

\begin{tabular}{|c|c|c|c|c|c|c|c|c|}
\hline Treatment & 6 & 7 & 8 & 9 & 10 & 11 & 12 & 13 \\
\hline 1 & 0.002 & 0.000001 & & 0.000006 & 0.0001 & & 0.00 & 0.003 \\
\hline 2 & 0.009 & 0.000004 & & 0.000031 & 0.0004 & & 0.0000021 & 0.01 \\
\hline 3 & & 0.002 & & 0.01 & & & 0.001 & \\
\hline 4 & & 0.003 & & 0.01 & & & 0.002 & \\
\hline 7 & & & 0.03 & & & 0.003 & & \\
\hline 8 & & & & & & & 0.02 & \\
\hline 9 & & & & & & 0.013 & & \\
\hline 11 & & & & & & & 0.0016 & \\
\hline
\end{tabular}

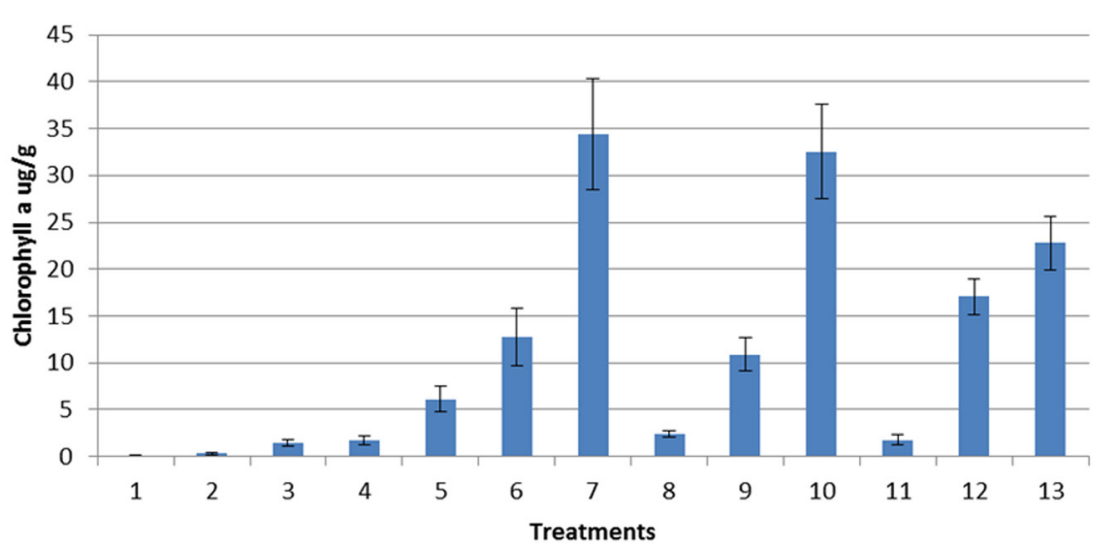

Figure 1: Mean chlorophyll-a concentrations in different treatments (1-13 listed in Table 1) following 6-week incubation. 
Table 4: Genera present in the tailings material before inoculation and following 6-week treatment

\begin{tabular}{|c|c|c|c|c|c|c|c|c|c|c|c|c|c|c|}
\hline \multirow{2}{*}{ Genus } & \multicolumn{14}{|c|}{ Treatment } \\
\hline & Before & 1 & 2 & 3 & 4 & 5 & 6 & 7 & 8 & 9 & 10 & 11 & 12 & 13 \\
\hline \multicolumn{15}{|c|}{ Cyanobacteria } \\
\hline Arthrospira & & & & & & & $\checkmark$ & & & & & & & \\
\hline Calothrix & & $\checkmark$ & & & & & & & & & & & & \\
\hline Lyngbya & & & & & & & & & & & & $\checkmark$ & & \\
\hline Microcoleus & & & & & & & $\checkmark$ & & & $\checkmark$ & & & $\checkmark$ & \\
\hline Nostoc & $\checkmark$ & & $\checkmark$ & $\checkmark$ & $\checkmark$ & $\checkmark$ & $\checkmark$ & $\checkmark$ & $\checkmark$ & & $\checkmark$ & $\checkmark$ & & $\checkmark$ \\
\hline Phormidium & $\checkmark$ & $\checkmark$ & $\checkmark$ & $\checkmark$ & $\checkmark$ & $\checkmark$ & $\checkmark$ & $\checkmark$ & $\checkmark$ & $\checkmark$ & $\checkmark$ & $\checkmark$ & $\checkmark$ & $\checkmark$ \\
\hline Scytonema & $\checkmark$ & $\checkmark$ & & & & & & & & & & & & \\
\hline \multicolumn{15}{|c|}{ Chlorophyta } \\
\hline Chlamydomonas & & $\checkmark$ & & $\checkmark$ & $\checkmark$ & $\checkmark$ & & $\checkmark$ & $\checkmark$ & & & $\checkmark$ & & $\checkmark$ \\
\hline Chlorella & & & & & & & & & & & & & & $\checkmark$ \\
\hline Chlorococcum & $\checkmark$ & $\checkmark$ & & $\checkmark$ & & & $\checkmark$ & & & & $\checkmark$ & & & \\
\hline Chlorolobion & & & & & & & & & & & $\checkmark$ & & & \\
\hline \multicolumn{15}{|l|}{ Chlorosarcinopsis } \\
\hline Klebsormidium & & & $\checkmark$ & & & & & & & & & & & \\
\hline Stichococcus & & & & & & & & & & & & & $\checkmark$ & \\
\hline Tetracystis & & & & $\checkmark$ & & & & $\checkmark$ & $\checkmark$ & $\checkmark$ & & & & \\
\hline \multicolumn{15}{|c|}{ Bacillariophyta } \\
\hline Navicula & & & & & & & & & & & & $\checkmark$ & & \\
\hline Total & 4 & 5 & 3 & 5 & 4 & 3 & 5 & 4 & 4 & 3 & 3 & 5 & 3 & 4 \\
\hline
\end{tabular}

See Table 1 for treatments.

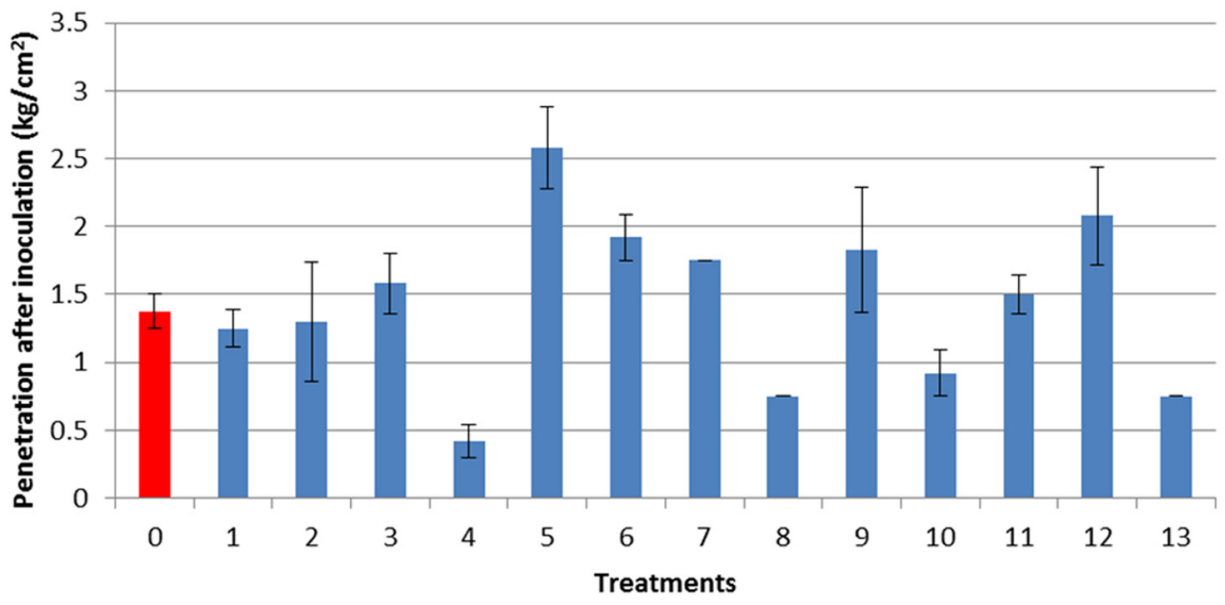

Figure 2: Results of soil penetration tests following treatment (see Table 1 for descriptions of treatments). The bar at 0 indicates penetration prior to inoculation. 
This method showed a continuous increase in biomass, probably because the agar buffers the organism against the sudden change from a liquid medium to the harsher conditions of the soil. This method was therefore used in further trials.

\section{Scanning electron microscopy}

Figure 3 shows SEM images of the different treatments with the soil algae and cyanobacteria. Phormidium sp. grew on the surface of the tailings material - even in the case of the control treatment that received only water (Figure 3a). Crust development can be initiated and helped with input of water, nutrients and inoculum (Figure 3b).
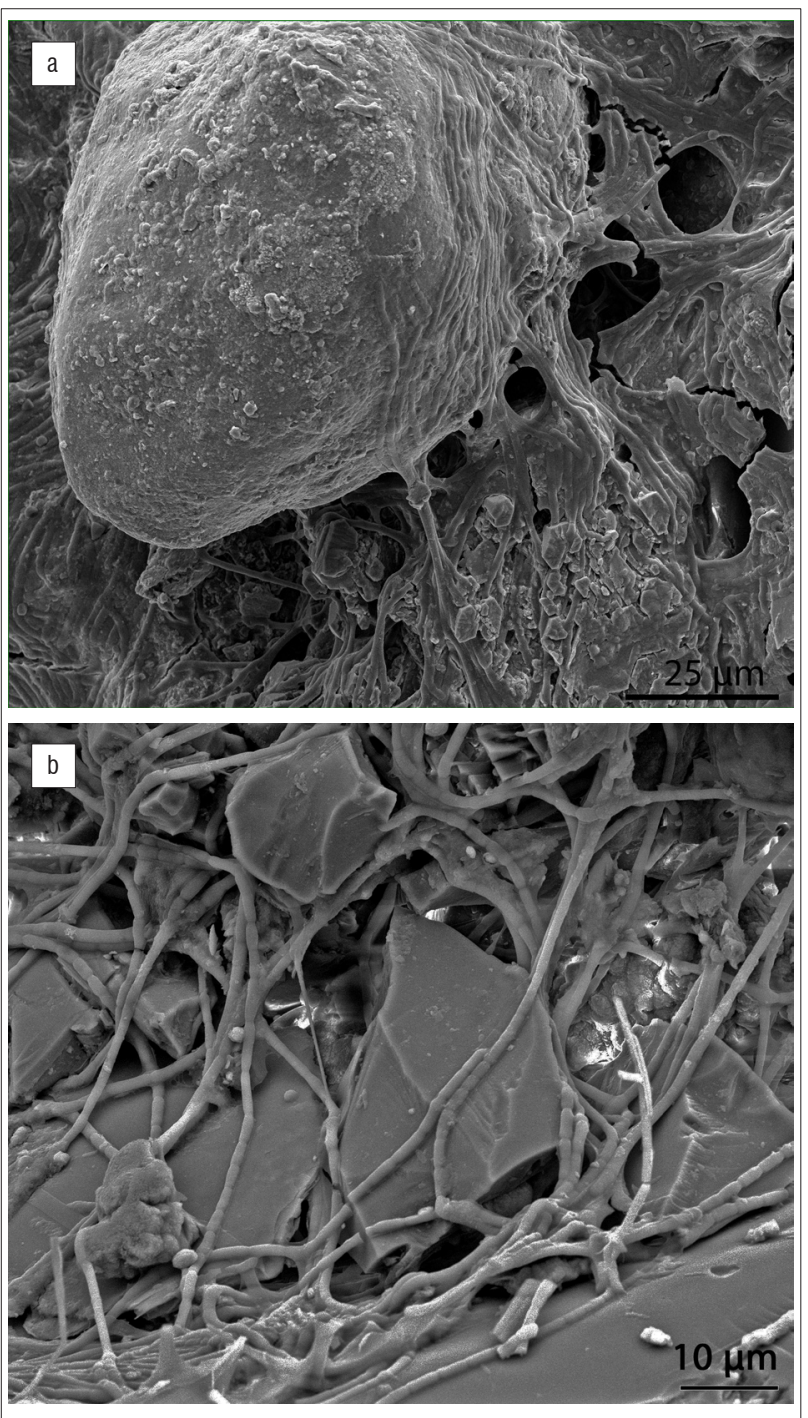

Figure 3: Scanning electron microscopy images showing the intimate relationship between algae, cyanobacteria and soil particles. (a) Control and (b) Treatment 9 after 6 weeks.

\section{Discussion}

The gold mine tailings material is acidic, has low cation exchange capabilities (CEC) and high electrical conductivity (EC; Table 2). According to Van Wyk ${ }^{25}$, the ideal CEC for South African soil is about $5-20 \mathrm{cmol} / \mathrm{kg}$ and ideal EC between 60 and $100 \mathrm{mS} / \mathrm{m}$. The CEC is the relative measure of the soil's ability to retain nutrients ${ }^{26}$ and nutrients are less likely to leach out if CEC is high ${ }^{27}$. Phosphate levels are very low and although calcium levels are high, calcium may not be available for utilisation by the organisms because of the low $\mathrm{pH}^{28}$ The availability of nutrients to plants is determined by the oxidative state and chemical properties of the element while the soil pH, interactions with soil colloids, microbial activity and soil physical conditions such as aeration, compaction, temperature and moisture also play key roles. ${ }^{29}$
In spite of the harsh substrate conditions, this study shows that algae and cyanobacteria are able to colonise gold mine tailings and produce a viable crust within 6 weeks. There were significant differences between the treatments with Nostoc and Microcoleus and the treatments in which no organism was added (Table 3). The Nostoc treatments also had the highest chlorophyll-a concentrations and the lower phosphate and nitrate concentrations did not inhibit the growth of this organism (Figure 1; Treatments 10 and 13). Nostoc is a small and mostly immobile cyanobacterium that resides mostly on the soil surface and usually has a mucopolysaccharide sheath and UV-protective pigmentation to protect it from radiation exposure, ${ }^{30}$ making it a good candidate to use as an inoculum on tailings material.

Better performance was expected from Microcoleus as BSC formation is often initiated by filamentous cyanobacteria such as Microcoleus ${ }^{31}$ followed by smaller cyanobacteria and chlorophytes ${ }^{32}$. Microcoleus is also a common soil cyanobacterium ${ }^{33}$ that occurred in most of the revegetated gold mine TSFs investigated by Orlekowsky et al. ${ }^{12}$ This organism has the ability to move around within the soil. When the soil is wet they can move towards the surface into the photosynthetic zone, while they retract deeper into the soil when the soil dries out. ${ }^{32}$ The continuous movement of the filaments in the soil ensures that sheath material is left behind in the soil layers thereby joining loose sand particles while forming a smooth biological soil crust on the soil surface. This type of crust may reduce water infiltration and can prevent the emergence of vascular plant seedlings ${ }^{34}$ but may be a good cover to prevent dust emissions from mine tailings.

Of the three organisms chosen for this investigation, Microcoleus presented the most difficulties to work with as it produces films on the bottom of the culture flasks, making it difficult to spread the inoculum evenly on the tailings material, causing patchy growth patterns. However, treatments with Microcoleus (Treatments 6, 9 and 12) differed significantly from the control treatments (1, 2 in Table 3$)$ and it is still a good candidate for inoculation on tailings material.

Chlorophytes such as Chlamydomonas are not pioneers and usually arrive later in ${ }^{32}$ the development of BSCs. This late arrival may explain the low chlorophyll-a concentrations measured for the Chlamydomonas treatments. However, treatments with Chlamydomonas penetrated the tailings material up to $641.5 \mu \mathrm{m}$ and it may help to stabilise the soil. Results indicated that Chlamydomonas Treatment 5 needed a force of $2.58 \mathrm{~kg} / \mathrm{cm}^{2}$ to break the crust. There was, however, no significant difference between the control and any of the treatments, emphasising that the crusts in all treatments were in a state of development.

The glasshouse trials were duplicated in field trials on TSFs with Nostoc and Microcoleus species (data not shown) and in spite of an untimely thunderstorm, preliminary results show a higher diversity in all the treatment plots after 6 weeks compared with those of the glasshouse trials, presumably as a result of the high diaspora concentration in the atmosphere surrounding the storage facilities.12 However, the chlorophyll-a concentrations measured were significantly lower $(<2 \mu \mathrm{g} / \mathrm{g})$ than those measured in the glasshouse trials.

\section{Conclusion}

This study was a preliminary one to determine if algae and cyanobacteria can grow on mine tailings; we have shown that with the inoculation of algae and cyanobacteria, as well as the input of moisture and nutrients, biological crusts can be established on tailings material within 6 weeks. Nostoc treatments had the highest chlorophyll-a concentrations and produced a surface crust, while Chlamydomonas treatments penetrated the tailings material and provided a stronger crust. Microcoleus species are more difficult to work with but this species also produced a viable crust, making it a good candidate to use as inoculum. By improving growth conditions, diaspora from algae and cyanobacteria in the environment also germinated on the tailings material, increasing the probability of forming viable biological crusts. One such organism is the filamentous cyanobacterium Phormidium that occurred on all the treatments after 6 weeks and may also be a good candidate to use as an inoculant. 
The results were promising but more research is necessary to determine the best organism, or combination of organisms, to colonise mine tailings and to eventually produce biological crusts. Moisture is very important and irrigation must be available when attempting field trials. The application of inoculum on a TSF must also be investigated as the conditions within a glasshouse are different from those of a TSF exposed to the outside environment.

\section{Acknowledgements}

We thank Eco-Analytica of the North-West University for performing the soil analyses.

\section{Authors' contributions}

F.v.W. conceptualised the project, acquired the funding and collected the data; T.S. undertook the data analysis and wrote the manuscript; T.S., A.V. and A.L. collected the data and analysed the samples; A.L. was responsible for student supervision; A.V. was the project leader, and was responsible for data curation and revisions; A.J. did the scanning electron microscopy.

\section{References}

1. Reichart M. A history of mine wastes rehabilitation techniques in South Africa: A multi-disciplinary overview of mine waste rehabilitation and the non-scientific drivers for its implementation 1950s - 1980s [PhD thesis]. Johannesburg: University of the Witwatersrand; 2012.

2. Haagner ASH. The role of vegetation in characterizing landscape function on rehabilitating gold tailings [MSc thesis]. Potchefstroom: North-West University; 2008

3. Hattingh JM, Van Deventer PW. The effect of the chemical properties of tailings and water application on the establishment of a vegetative cover on gold tailings dams. Water Research Commission report no. 899/1/04. Pretoria: Water Research Commission; 2004.

4. Smallhorne M. Joburg's iconic mine dumps are a health risk, say activists. Mail and Guardian. 2012 December 14; Arts and culture.

5. Mendez MO, Maier RM. Phytoremediation of mine tailings in temperate and arid environments. Rev Environ Sci Biotechnol. 2008;7(1):47-59. http:// dx.doi.org/10.1007/s11157-007-9125-4

6. Stevenson FJ, Cole MA. Cycles of soil: Carbon, nitrogen, phosphorus, sulphur, micronutrients. New York: John Wiley and Sons Inc.; 1999.

7. Moynahan OS, Zabinski CA, Gannon JE. Microbial community structure and carbon-utilization diversity in mine tailings revegetation study. Restor Ecol. 2002;10:77-87. http://dx.doi.org/10.1046/j.1526-100X.2002.10108.x

8. Blight $G$. Mine waste: A brief overview of origins, quantities, and methods of storage. In: Letcher T, Vallero D, editors. Waste: A handbook for management. Cambridge: Academic Press; 2011. p. 77-88. https://doi.org/10.1016/B9780-12-381475-3.10005-1

9. Shields LM, Durell LW. Algae in relation to soil fertility. Bot Rev. 1964;30(1):92128. http://dx.doi.org/10.1007/BF02858614

10. Eldridge DJ, Zaady E, Shachak M. Infiltration through three contrasting biological soil crusts in patterned landscapes in the Negev, Israel. Catena. 2000;40:322-336. http://dx.doi.org/10.1016/S0341-8162(00)00082-5

11. Venter A, Levanets A, Siebert S, Rajakaruna N. A preliminary survey of the diversity of soil algae and cyanoprokaryotes on mafic and ultramafic substrates in South Africa. Austral J Bot. 2015;63:341-352. http://dx.doi. org/10.1071/BT14207

12. Orlekowsky T, Venter A, Van Wyk F, Levanets A. Cyanobacteria and algae of gold mine tailings in the Northwest Province of South Africa. Nov Hedw. 2013;97(3-4):281-294. http://dx.doi.org/10.1127/0029-5035/2013/0117

13. Frouz J, Keplin B, Pizl V, Tajovsky K, Stary J, Lukesova A, et al. Soil biota and upper soil layer development in two contrasting post-mining chronosequences. Ecol Eng. 2001;17:275-284. http://dx.doi.org/10.1016/ S0925-8574(00)00144-0
14. Lange OL. Photosynthesis of soil-crust biota as dependent on environmental factor. In: Belnap J, Lange OL, editors. Biological soil crusts: Structure, function, and management. Berlin: Springer; 2001. p. 217-240. https://doi. org/10.1007/978-3-642-56475-8_18

15. Hu C, Zhang D, Huang Z, Liu Y. The vertical microdistribution of cyanobacterial and green algae within desert crusts and the development of the algal crusts. Plant Soil. 2003;257:97-111. https://doi.org/10.1023/A:1026253307432

16. Flechtner V. North American desert microbiotic soil crust communities: Diversity despite challenge. In: Seckbach J, editor. Algae and cyanobacteria in extreme environments. Dordrecht: Springer; 2007. p. 539-551. https://doi. org/10.1007/978-1-4020-6112-7_29

17. Bowker MA. Biological soil crust rehabilitation in theory and practice: An underexploited opportunity. Restor Ecol. 2007;15(1):13-23. http://dx.doi. org/10.1111/j.1526-100X.2006.00185.x

18. Issa OM, Défarge C, Bissonnais YL, Marin B, Duval O, Bruand A, et al. Effects of the inoculation of cyanobacteria on the microstructure and the structural stability of a tropical soil. Plant Soil. 2007;290(1-2):209-219. http://dx.doi. org/10.1007/s11104-006-9153-9

19. Non-Affiliated Soil Analysis Work Committee, Soil Science Society of South Africa. Handbook of standard soil testing methods for advisory purposes. Pretoria: Soil Science Society of South Africa; 1990.

20. Brown RM, Larson DA, Bold HC. Airborne algae: Their abundance and heterogeneity. Science. 1964;143(3606):583-585. http://dx.doi. org/10.1126/science. 143.3606 .583

21. Stein JR. Handbook of phycological methods and culture methods and growth measurements. Cambridge: Cambridge University Press; 1973.

22. Castle SC. Chlorophyll-a double extraction with methanol. Boulder, CO: Aridlands Ecology Laboratory, University of Colorado; 2010.

23. Porra RJ, Thompson WA, Kriedeman PE. Determination of accurate extinction coefficients and simultaneous equations for assaying chlorophylls $a$ and $b$ extracted with four different solvents: Verification of the concentration of chlorophyll standards by atomic spectroscopy. Biochim Biophys Acta. 1989;975:384-394. https://doi.org/10.1016/S0005-2728(89)80347-0

24. Tiedt LR, Jooste WJ, Hamilton-Attwell VL. Technique for preserving aerial fungus structures for scanning electron microscopy. Trans Br Mycol Soc. 1987;88(3):420-422. https://doi.org/10.1016/S0007-1536(87)80021-9

25. Van Wyk SJ. An analytical investigation of the biophysical factors that inhibit successful ecological restoration of gold tailings dams [MEnvSci thesis]. Potchefstroom: North-West University; 2002.

26. Winegardner DL. An introduction to soils for environmental professionals. Boca Raton, FL: CRC/Lewis Publishers; 1995.

27. Hardy DH, Tucker MR, Messick JK, Stokes C. Understanding the soil test report. Raleigh, NC: Agronomic Division, North Carolina Department of Agriculture \& Consumer Services; 2012.

28. Miles N, Farina M. Soil acidity and its management in crop production [homepage on the Internet]. c2013 [cited 2016 Nov 27]. Available from: http:// www.grainsa.co.za/soil-acidity-and-its-management-in-crop-production

29. Hodges SC. Soil fertility basics: NC Certified Crop Advisor Training. Raleigh, NC: Soil Science Extension, North Carolina State University; 2010.

30. Belnap J, Phillips SL, Miller ME. Response of desert biological soil crusts to alterations in precipitation frequency. Oecologia. 2004;141:306-316. https:// doi.org/10.1007/s00442-003-1438-6

31. Mager DM, Hui CA. A first record of biological crusts in the Cape Floristic Region. S Afr J Sci. 2012;108(7/8), Art. \#1013, 4 pages. http://dx.doi. org/10.4102/sajs.v108i7/8.1013

32. Belnap J. Factors influencing nitrogen fixation and nitrogen release in biological soil crusts. In: Belnap J, Lange OL, editors. Biological soil crusts: Structure, function, and management. Berlin: Springer; 2003. p. 241-261. https://doi.org/10.1007/978-3-642-56475-8

33. Metting B. The systematics and ecology of soil algae. Bot Rev. 1981;47(2):195-312. http://dx.doi.org/10.1007/BF02868854

34. Belnap J, Eldridge D, Hilty-Kaltenecker J, Leonard S, Rosentreter R. Biological soil crusts: Ecology and management. Technical reference 1730-2. Denver, C0: United States Department of the Interior Bureau of Land Management; 2001. 